\title{
POTENSI EKSTRAK ETANOL BAWANG MERAH (Allium ascolonicum L.) DAN GARAM NaCI MENURUNKAN LUAS AREA SERTA MENINGKATKAN KONTRAKSI JARINGAN LUKA BAKAR RINGAN
}

\author{
I M. Sukadana*, S. R. Santi dan Melli
}

Program Studi Kimia Fakultas Matematika dan Ilmu Pengetahuan Alam Universitas Udayana *Email: im_sukadana@unud.ac.id

\begin{abstract}
ABSTRAK
Luka bakar (burns) merupakan respon kulit dan jaringan subkutan terhadap trauma suhu atau termal yang berdampak pada kerusakan kulit. Berat atau ringannya kerusakan jaringan akibat luka bakar dipengaruhi oleh beberapa faktor antara lain kedalaman luka bakar, luas luka bakar, lokasi luka bakar, kesehatan tubuh secara umum, mekanisme cedera dan usia. Luas area luka bakar dan persentase kontraksi luka merupakan indikator proses penyembuhan luka bakar ringan. Penelitian ini menggunakan 25 ekor tikus wistar yang dibagi menjadi 5 kelompok perlakuan dengan rancangan randomized posttest only control group design sebagai berikut; K: diberi perawatan vaselin (kontrol negatif), $\mathrm{K}_{\mathrm{p}}$ : diberi perawatan bioplacenton (kontrol positif), $\mathrm{P}_{1}$ : diberi perawatan garam dapur pada konsentrasi 7,5\% dalam vaselin, $\mathrm{P}_{2}$ : diberi perawatan ekstrak bawang merah pada konsentrasi $40 \%$ dalam vaselin, dan $\mathrm{P}_{3}$ : diberi perawatan campuran ekstrak bawang merah $40 \%$ dan garam dapur pada konsentrasi 7,5\% dalam vaselin. Hasil penelitian dan analisis statistik One-Way ANOVA dan Post Hoc Test LSD menggunakan program SPSS for Windows versi 19 menunjukkan kelompok perlakuan $\mathrm{P}_{2}$ yaitu ekstrak etanol bawang merah dengan konsentrasi $40 \%$ memberikan hasil terbaik sehingga sangat berpotensi untuk dikembangkan lebih lanjut sebagai bahan obat luka bakar ringan dibandingkan kelompok perlakuan $\mathrm{P}_{1}$ maupun $\mathrm{P}_{3}$ karena kemampuannya menurunkan luas area dari $340,79 \mathrm{~mm}^{2}$ dihari ke-1 menjadi $11,75 \mathrm{~mm}^{2}$ serta meningkatkan kontraksi luka sebesar $81,59 \%$ di akhir perawatan.
\end{abstract}

Kata kunci: Allium ascolonicum L., diameter luka, kontraksi luka dan luka bakar ringan

\begin{abstract}
Burns is a skin response and subcutaneous tissue to temperature or thermal trauma that affects skin damage. The weight or severity of tissue damage from burns is influenced by several factors including deep burns, burns area, burn location, general body health, injury mechanism and age. The area of burns and the percentage of wound contractions is an indicator of the healing process of minor burns. This study used 25 wistar rats divided into 5 treatment groups with randomized posttest only control group design as follows; K: given vaseline treatment (negative control), $\mathrm{K}_{\mathrm{p}}$ : given bioplacenton treatment (positive control), $\mathrm{P}_{1}$ : given salt treatment at $7.5 \%$ concentration in vaseline, $\mathrm{P}_{2}$ : given onion extract treatment at $40 \%$ concentration in vaseline, and $\mathrm{P}_{3}$ : given a mixture of onion extract $40 \%$ and kitchen salt at a concentration of 7,5\% in vaseline. The result of One-Way ANOVA and Post Hoc Test LSD using SPSS for Windows version 19 shows $\mathrm{P}_{2}$ treatment group is onion extract of $40 \%$ give the best result concentration of onion extract so it is very potential to be developed further as light burning agent compared to $\mathrm{P}_{1}$ and $\mathrm{P}_{3}$ treatment group because of its ability to decrease the area of $340,79 \mathrm{~mm}^{2}$ on the first day to $11,75 \mathrm{~mm}^{2}$ and increased wound contraction by $81,59 \%$ at the end of treatment.
\end{abstract}

Keywords: Allium ascolonicum L., wound diameter, wound contraction and minor burns

\section{PENDAHULUAN}

Luka bakar (burns) merupakan respon kulit dan jaringan subkutan terhadap trauma suhu atau termal yang berdampak pada kerusakan kulit sebagai akibat kontak langsung atau terpapar dengan sumber-sumber panas seperti api (thermal), listrik (electrict), zat kimia (chemical), atau radiasi (radiation) (Nurdiana dkk., 2008). Luka bakar merupakan penyebab kematian ketiga akibat kecelakaan pada semua kelompok umur, dan laki-laki cenderung lebih sering mengalami luka bakar dari pada wanita, terutama pada orang tua atau lanjut usia (umur diatas 70 tahun) (Hidayat, 2009). 
Penanganan medis pada kasus luka bakar biasanya dilakukan pada menit-menit awal ketika bagian tubuh terpapar sumber panas. Penanganan untuk luka bakar ringan yang mudah, murah, dan cepat biasanya menggunakan tumbuhan lidah buaya dan pasta gigi, sedangkan secara tradisional masyarakat umumnya menggunakan kecap, minyak, maupun menaburkan serbuk kopi ke daerah luka bakar. Untuk luka bakar ringan dengan kedalaman tertentu misalnya berderajat II A diperlukan waktu penyembuhan yang cepat untuk menekan pertumbuhan bakteri. Burn wound dressing atau agen antimikroba topikal biasanya digunakan untuk melembabkan lingkungan luka sehingga mengoptimalkan proses epitelisasi dan melindungi kulit dari infeksi mikroorganisme. Namun penggunaan burn wound dressing atau obat-obatan antimikroba topikal masih terkendala dengan harganya yang relatif tidak murah, sehingga perlu diupayakan pencarian bahan-bahan lain baik yang bersumber dari bahan alam hayati maupun non hayati yang dapat dimanfaatkan untuk penanganan luka bakar ringan berderajat II A.

Salah satu sumber daya alam non hayati dan hayati yang dapat dipergunakan untuk penanganan luka bakar ringan dengan tingkat kerusakan jaringan kulit sampai superficial dan dermis (derajat II A) adalah garam dapur dan bawang merah (Allium ascolonicum L). Larutan normal saline $(\mathrm{NaCl} 0,9 \%)$ maupun hipertonik $(\mathrm{NaCl} \quad 7,5 \%) \quad$ sering kali dipergunakan untuk perawatan luka bakar oleh karena bersifat fisiologis dan non toksik sehingga cenderung tidak memberikan efek hipersensitifitas (InETNA, 2004), menjaga kelembaban luka sehingga membantu proses penyembuhan luka melalui proses percepatan epitelisasi, namun tidak melindungi luka bebas dari mikroorganisme, sedangkan larutan garam hipertonik dipergunakan sebagai perawatan dan penyembuhan luka bakar (Murphy et al., 1999) dengan memberikan perlindungan terhadap infeksi bakteri dan pertumbuhan sepsis melalui peningkatan respon inflamasi (Junger et al., 1997; Hartl et al., 1997). Bawang merah secara etnobotani mempunyai aktivitas fisiologis mencegah kerusakan sel, antibakteri, meningkatkan aktivitas fibrinolitik sehingga memperlancar aliran darah, serta sebagai obat luka. Ekstrak etanol bawang merah dengan konsentrasi 40\% mampu menghambat pertumbuhan bakteri Staphylococcus aureus dengan diameter zona hambatan sebesar 0,957 $\mathrm{cm}^{2}$ (Angela, 2013).

Berdasarkan penggunaannya secara tradisional serta belum adanya informasi pengujian secara ilmiah mengenai pemanfaatan garam dapur dan bawang merah sebagai pertolongan pertama serta perawatan pada kasus luka bakar ringan berderajat II A, maka perlu dilakukan penelitian ini untuk membuktikan apakah bawang merah dan garam dapur berpotensi dalam proses penyembuhan luka bakar ringan melalui indikator penurunan diameter dan peningkatan kontraksi luka.

\section{MATERI DAN METODE}

\section{Bahan Penelitian}

Bahan tumbuhan bawang merah (Allium ascolanicum L.) telah dideterminasi di Balai Konservasi Tumbuhan Kebun Raya "Eka Karya" Bali. Tikus wistar (Rattus norvegicus) jantan umur 75-90 hari, berat 230-250 g telah dinyatakan laik etik oleh Komisi Etik Penggunaan Hewan dalam Penelitian dan Pendidikan Fakultas Kedokteran Hewan UNUD No. 0140/KE-PH/VII/2017 tanggal 23 Januari 2017. Bahan kimia yang digunakan antara lain etanol p.a, etanol teknis, kloroform p.a, n-heksana p.a, dietileter teknis, garam dapur $(\mathrm{NaCl})$, pereaksi fitokimia, akuades, veet, bioplacenton, dan vaselin.

\section{Peralatan Penelitian}

Alat yang dipergunakan meliputi seperangkat alat gelas, penguap putar vakum (rotary vacuum evaporator), pisau, kertas saring, blender, pipet tetes, tabung reaksi dan rak, penjepit tabung reaksi, plat tetes, botol tempat sampel, kandang tikus, timbangan analitik, spatel, penggaris, gunting, alat cukur, pinset, cawan petri, kassa steril, plester, stopwatch, uang logam berdiameter $2,5 \mathrm{~cm}$, kamera (Nikon MH-70 dan Canon A 530).

\section{Prosedur Pembuatan Ekstrak Etanol Bawang Merah dan Pengujian Luka Bakar}

Bawang merah sebanyak $1 \mathrm{~kg}$ dimaserasi basah menggunakan pelarut etanol 96\% sebanyak $500 \mathrm{~mL}$. Setiap 24 jam ekstrak tersebut disaring dan diganti pelarutnya dengan 
$300 \mathrm{~mL}$ etanol $96 \%$ yang baru. Proses maserasi ini dilakukan 3 kali sampai diperkirakan semua senyawa yang terkandung didalamnya terekstrak habis. Ekstrak kental etanol yang diperoleh ditimbang beratnya dan diaplikasikan pada 25 ekor tikus coba yang dikelompokkan menjadi 5 kelompok berdasarkan randomized posttest only control group design sebagai berikut:

$$
\begin{aligned}
& \mathrm{K}= \begin{array}{l}
\text { kelompok tikus wistar luka } \\
\text { bakar diberi perawatan vaselin } \\
\text { (kontrol negatif) }
\end{array} \\
& \mathrm{K}_{\mathrm{p}}= \begin{array}{l}
\text { kelompok tikus wistar luka } \\
\text { bakar diberi perawatan } \\
\text { bioplacenton (kontrol positif) }
\end{array} \\
& \mathrm{P}_{1}= \begin{array}{l}
\text { kelompok tikus wistar diberi } \\
\text { perawatan garam dapur pada }
\end{array} \\
& \text { konsentrasi 7,5\% dalam vaselin } \\
& \text { kelompok tikus wistar diberi } \\
& \mathrm{P}_{2}= \\
& \text { perawatan ekstrak bawang } \\
& \text { merah pada konsentrasi 40\% } \\
& \text { dalam vaselin } \\
& \text { kelompok tikus wistar diberi } \\
& \text { perawatan campuran ekstrak } \\
& \text { bawang merah 40\% dan garam } \\
& \text { dapur pada konsentrasi 7,5\% } \\
& \text { dalam vaselin. }
\end{aligned}
$$

Luka bakar ringan pada tikus dibuat dengan teknik kontak panas menggunakan uang logam. Bagian punggung tikus yang akan dibuat luka dicukur bulunya menggunakan Veet sekitar $3 \mathrm{~cm}$, kemudian didesinfeksi menggunakan etanol. Uang logam yang berdiameter $\pm 3 \mathrm{~cm}$ dibungkus kain kassa lalu dimasukkan ke dalam minyak kelapa panas $\left(50^{\circ} \mathrm{C}-60^{\circ} \mathrm{C}\right)$ selama 5 menit. Uang logam panas ini selanjutnya ditempelkan pada bagian punggung tikus yang telah dianastesi sebelumnya selama 25 detik. Sebelum treatmen luka bakar dibersihkan dengan larutan $\mathrm{NaCl} 0,9 \%$ selanjutnya diolesi ekstrak umbi bawang merah dengan berbagai konsentrasi uji.

Bahan uji dioleskan secara merata sampai menutupi luka $1 \mathrm{kali} / \mathrm{hari}$ setiap jam 09.00 pagi mulai hari ke-1 sampai hari ke-10 perawatan. Pengukuran diameter luka bakar dilakukan setiap hari, menggunakan jangka sorong yang dinyatakan sampai $0,1 \mathrm{~mm}$ terdekat. Perhitungan persentase kontraksi luka dilakukan mulai hari ke-2 sampai dengan hari ke-10 (Wijaya, 2012) Identifikasi golongan senyawa yang terkandung pada ekstrak aktif bawang merah ditentukan dengan pereaksi fitokimia.

\section{HASIL DAN PEMBAHASAN}

\section{Luas Area Luka Bakar}

Pengukuran diameter luka dalam penelitian ini dilakukan mulai batas warna jaringan kemerahan sisi sebelah dalam dari pinggiran luka yang berwarna kuning. Berdasarkan pengukuran diameter luka maka dapat dihitung luas area luka bakar tiap tikus untuk masing-masing kelompok kontrol ( $\mathrm{K}$ dan $\left.\mathrm{K}_{\mathrm{p}}\right)$ dan perlakuan $\left(\mathrm{P}_{1}, \mathrm{P}_{2}\right.$, dan $\left.\mathrm{P}_{3}\right)$ seperti dipaparkan dalam Gambar 1 sebagai berikut:

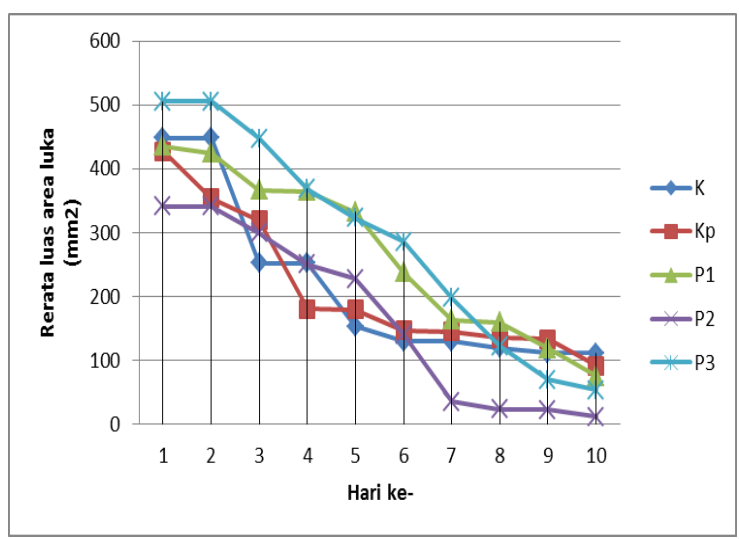

Gambar 1. Rerata luas area luka bakar untuk kelompok $\mathrm{K}, \mathrm{K}_{\mathrm{p}}, \mathrm{P}_{1}, \mathrm{P}_{2}$, dan $\mathrm{P}_{3}$ mulai hari ke-1 sampai hari ke-10 perawatan

Luas area merupakan salah satu indikasi proses penyembuhan luka bakar. Luas area suatu luka bakar ditentukan berdasarkan pembentukan jaringan epitel luka. Penurunan luas area luka bakar ditunjukkan dengan terjadinya perubahan warna luka dari putih pucat, mulai kemerahan dan merah kehitaman sampai akhirnya bagian pinggir luka berangsur-angsur menebal dan keriput serta terjadi perubahan warna jaringan dari berwarna kemerahan menjadi kuning. Timbulnya warna kemerahan pada luka menunjukkan proses epitelisasi mulai terjadi yang disebabkan oleh senyawa yang terkandung dalam bawang merah yang dapat meningkatkan aktivitas 
fibrinolitik sehingga aliran darah menjadi lebih lancar dan proses penyembuhan mulai terjadi.

\section{Kontraksi Luka Bakar}

Kontraksi luka merupakan salah satu tahap penyembuhan luka yang termasuk dalam fase proliferasi karena pada tahap ini mulai terjadi penyempitan luka. Pada kontraksi luka ada pergerakan sentripetal seluruh kulit, namun demikian mekanismenya belum diketahui secara pasti, diduga proses kontraksi ini disebabkan oleh kontraksi dari fibroblas yaitu miofibroblas yang mendorong tepi luka sehingga ukuran luka menjadi berkurang sampai $60 \%$ dalam jangka waktu 10 hari (Sabiston, 2000). Hasil perhitungan persentase kontraksi luka untuk setiap tikus dari masingmasing perlakuan mulai dari hari ke-2 sampai dengan hari ke-10 perawatan dipaparkan dalam Gambar 2 sebagai berikut:

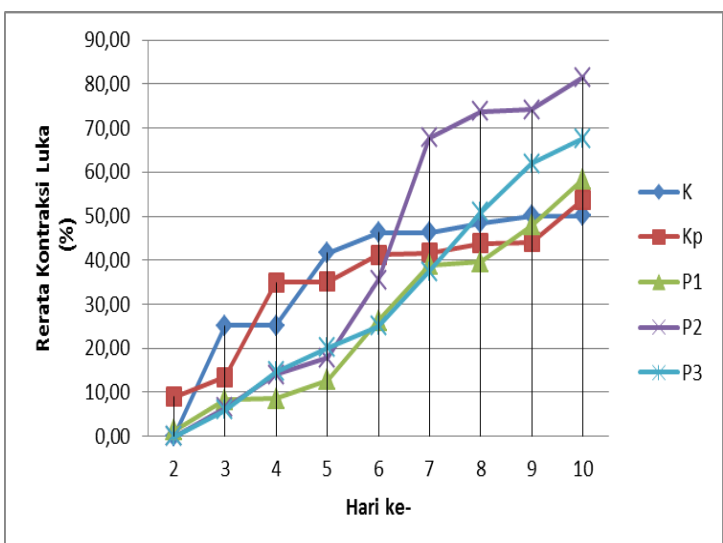

Gambar 2. Rerata persentase kontraksi luka bakar untuk kelompok $\mathrm{K}, \mathrm{K}_{\mathrm{p}}, \mathrm{P}_{1}$, $\mathrm{P}_{2}$, dan $\mathrm{P}_{3}$ mulai hari ke-1 sampai hari ke-10 perawatan

Perlakuan garam dapur 7,5\% $\left(\mathrm{P}_{1}\right)$ menurunkan persentase kontraksi luka yang berbeda secara signifikan terhadap kontrol negatif (K) maupun kontrol positif atau Bioplacenton $\left(\mathrm{K}_{\mathrm{p}}\right)$. Kemampuan garam dapur dalam penyembuhan luka disebabkan oleh komposisi utama penyusun garam dapur yaitu $\mathrm{NaCl}$ yang mempunyai sifat penyerap panas karena keadaan kisi kristalnya berbentuk kubus, di mana satu ion $\mathrm{Na}^{+}$diikat oleh enam ion $\mathrm{Cl}^{-}$sehingga terdapat banyak rongga yang berfungsi untuk menyerap panas. Terserapnya panas pada saat awal tikus coba terpapar panas akan mengurangi dampak lanjut kerusakan jaringan kulit lebih dalam. Garam dapur juga mampu memberikan perlindungan terhadap infeksi bakteri dan pertumbuhan sepsis melalui peningkatan respon inflamasi akut (Junger et al., 1997; Harlt et al., 1997) sehingga memberikan efek pada penyembuhan luka bakar. Namun demikian perlakuan $\mathrm{P}_{2}$ yaitu pemberian ekstrak bawang merah konsentrasi $40 \%$ memberikan hasil terbaik dalam menyembuhkan luka bakar ringan derajat II A dilihat dari penurunan diameter luka dan peningkatan persentase kontraksi luka selama 10 hari pengamatan. Hasil uji fitokimia menunjukkan bahwa ekstrak aktif mengandung flavonoid, fenolat dan triterpenoid. Kemampuan bawang merah dalam proses penyembuhan luka bakar diduga disebabkan kandungan senyawa kuersetin (golongan flavonol), yang bersifat antioksidan dan antiinflamasi (Filomena, et al., 2007; Kurniawati, 2010). Sifat antioksidannya dapat memutus rantai radikal bebas dengan menangkap radikal bebas dari paparan panas yang diberikan pada hewan coba sehingga dapat meningkatkan oksigenasi, mencegah terjadinya kerusakan jaringan lebih lanjut dengan meningkatkan pembentukan pembuluh darah dan jumlah fibroblas serta menginduksi sistem seluler antioksidan dengan meningkatkan sekitar 50\% konsentrasi seluler glutathione dalam tubuh dan terjadi proses peningkatan kontraksi luka. Sifat antiinflamasinya sangat berguna bagi pertahanan tubuh karena dapat mencegah penyebaran infeksi ke jaringan lain dan mempercepat proses penyembuhan.

\section{SIMPULAN}

Hasil penelitian dapat disimpulkan:

1. Garam dapur dengan konsentrasi $7,5 \%$ dapat menyembuhkan luka bakar ringan berderajat II A pada tikus wistar terpapar panas karena mampu menurunkan luas area dari 435,87 $\mathrm{mm}^{2}$ dihari ke-1 menjadi $75,53 \mathrm{~mm}^{2}$ dan meningkatkan kontraksi luka sebesar 58,39\% di akhir perawatan.

2. Ekstrak etanol bawang merah dengan konsentrasi $40 \%$ dapat menyembuhkan luka bakar ringan berderajat II A pada tikus wistar terpapar panas karena mampu menurunkan luas area dari $340,79 \mathrm{~mm}^{2}$ dihari ke-1 menjadi $11,75 \mathrm{~mm}^{2}$ dan 
meningkatkan kontraksi luka sebesar $81,59 \%$ di akhir perawatan.

3. Kombinasi garam dapur dengan konsentrasi $7,5 \%$ dan ekstrak etanol bawang merah dengan konsentrasi $40 \%$ dapat menyembuhkan luka bakar ringan berderajat II A pada tikus wistar terpapar panas karena mampu menurunkan luas area dan dari 505,16 $\mathrm{mm}^{2}$ dihari ke-1 menjadi $53,23 \mathrm{~mm}^{2}$ dan meningkatkan kontraksi luka sebesar $67,60 \%$ di akhir perawatan.

\section{UCAPAN TERIMA KASIH}

Ucapan terima kasih kami sampaikan kepada Universitas Udayana melalui Dana Hibah HUPS PNBP Fakultas Matematika dan Ilmu Pengetahuan Alam Tahun Anggaran 2016/2017 dan LPPM Universitas Udayana yang telah memfasilitasi kegiatan penelitian.

\section{DAFTAR PUSTAKA}

Angela S., 2013, Antibakteri Ekstrak Etanol Umbi Lapis Bawang Merah (Allium cepa L) Terhadap Pertumbuhan Staphylococcus aureus dan Escherichia coli, Calyptra: Jurnal Ilmiah Mahasiswa Universitas Surabaya, 2:1.

Filomena, C., Silvio., S., Mariangela, M., Federica, M., Giancarlo, A.S., Dimitar, U., Aurelia, T., Francesco, M., and Roberto, D.L., 2007, In Vivo Antiinflammatory and In Vitro Antioxidant Activities of Mediterranean Dietary Plants. Journal of Ethnopharmaclogy, 116 (2008): 144-151.

Hartl, R., Medary, M.B., Ruge, M., Arfors, K.E., Ghahremani, F., and Ghajar, J., 1997, Hypertonic/Hyperoncotic Saline Attenuates Microcirculatory Disturbances after Traumatic Brain Injury, J Trauma, 42 (5): 4-7.
Hidayat, 2009, Asuhan Keperawatan Klien Luka Bakar, available from: http://hidayat2.wordpress.com/2009/07/ 05/askep-luka-bakar/, tanggal akses 16 Agustus 2011.

Indonesia Enterostomal Therapy Nurse Association (InETNA) \& Tim Perawatan luka dan Stoma Rumah Sakit Dharmais, 2004, Perawatan Luka, Makalah Mandiri, Jakarta.

Junger WG, Coimbra R., and Liu FC, 1997, Hypertonic Saline Resuscitation: a Tool to Modulate Immune Function in Trauma Patients, Shock, 8: 235-41.

Kurniawati, N., 2010, Sehat \& Cantik Alami berkat Khasiat Bumbu Dapur, Qanita. Bandung, h. 117-119.

Murphy, J.T., Horton, J.W., Purdue, G.F., and Hunt, J.L., 1999, Cardiovascular Effect of $7.5 \%$ Sodium Chloride-dextran Infusion after Thermal Injury, Arch Surg, 134:1091-7.

Nurdiana, dkk, 2008, Perbedaan Kecepatan Penyembuhan Luka Bakar Derajat II Antara Perawatan Luka Menggunakan Virgin Coconut Oil (Cocos nucifera) dan Normal Salin pada Tikus Putih (Rattus norvegicus) Strain Wistar, Malang: Fakultas Kedokteran Universitas Brawijaya.

Sabiston, D., 2000, Buku Ajar Bedah, Alih Bahasa Petrus Adrianto dan Timen, I.S., EGG, Jakarta.

Wijaya, A., 2012, Pengaruh Pemberian Berbagai Coconut Oil Secara Topikal Terhadap Penyembuhan Luka Bakar kimiawi Pada Kulit Tikus Putih (Rattus norvegicus) Terinduksi Asam Sulfat, FKIK (Pendidikan Dokter) 8 (9): 1-11. 